\title{
Adherence to highly active antiretroviral therapy and its correlates among HIV infected pediatric patients in Ethiopia Sibhatu Biadgilign ${ }^{1}$, Amare Deribew ${ }^{1}$, Alemayehu Amberbir ${ }^{2}$ and Kebede Deribe*3
}

Address: ${ }^{1}$ Jimma University, Public Health Faculty, Department of Epidemiology and Biostatistics, Jimma, Ethiopia, ${ }^{2}$ Addis Ababa University, School of Public Health, Butajira Birth cohort project, Addis Ababa, Ethiopia and ${ }^{3}$ Fayyaa Integrated Development Association-NCMI, PEPFARNew Partners Initiative, P.O. Box 19715 Addis Ababa, Ethiopia

Email: Sibhatu Biadgilign - sibhatu2005@yahoo.com; Amare Deribew - amare_deribew@yahoo.com; Alemayehu Amberbir - alamwo1@yahoo.com; Kebede Deribe* - kebededeka@yahoo.com

* Corresponding author

Published: 6 December 2008

BMC Pediatrics 2008, 8:53 doi:10.1 |86/147|-2431-8-53
Received: 5 August 2008

Accepted: 6 December 2008

This article is available from: http://www.biomedcentral.com/I47I-243I/8/53

(C) 2008 Biadgilign et al; licensee BioMed Central Ltd.

This is an Open Access article distributed under the terms of the Creative Commons Attribution License (http://creativecommons.org/licenses/by/2.0), which permits unrestricted use, distribution, and reproduction in any medium, provided the original work is properly cited.

\begin{abstract}
Background: The introduction of combination antiretroviral therapy (ART) has resulted in striking reductions in HIV-related mortality. Despite increased availability of ART, children remain a neglected population. This may be due to concerns that failure to adhere appears to be related to continued viral replication, treatment failure and the emergence of drug-resistant strains of HIV. This study determines the rates and factors associated with adherence to Antiretroviral (ARV) Drug therapy in HIV-infected children who were receiving Highly Active Antiretroviral Therapy (HAART) in Addis Ababa, Ethiopia in 2008.
\end{abstract}

Methods: A cross-sectional study was conducted in five hospitals in Addis Ababa from February 18 - April 28, 2008. The study population entailed parents/caretaker and index children who were following ART in the health facilities. A structured questionnaire was used for data collection.

Results: A total of 390 children respondents were included in the study with a response rate of $91 \%$. The majority, equaling 205 (52.6\%) of the children, were greater than 9 years of age. Fifty five percent of the children were girls. A total of 339 children (86.9\%) as reported by caregivers were adherent to antiretroviral drugs for the past 7 days before the interview. Numerous variables were found to be significantly associated with adherence: children whose parents did not pay a fee for treatment $[O R=0.39(95 \% \mathrm{Cl}: 0.16,0.92)]$, children who had ever received any nutritional support from the clinic $[O R=0.34(95 \% \mathrm{Cl}: 0.14,0.79)]$ were less likely to adhere. Whereas children who took co-trimoxazole medication/syrup besides ARVs [OR $=3.65(95 \% \mathrm{Cl}: 1.24,10.74)]$, children who did not know their sero-status $[\mathrm{OR}=2.53(95 \% \mathrm{Cl}$ : $1.24,5.19)]$ and children who were not aware of their caregiver's health problem $[\mathrm{OR}=2.45(95 \% \mathrm{Cl}: 1.25,4.8 \mathrm{I})]$ were more likely to adhere than their counterparts.

Conclusion: Adherence to HAART in children in Addis Ababa was higher than other similar setups. However, there are still significant numbers of children who are non-adherent to HAART. 


\section{Background}

HIV/AIDS is one of the most destructive epidemics the world has ever witnessed. In 2007 an estimated 33.2 million people were living with HIV (PLHIV) worldwide, while 2.5 million of these people were children under 15 years old. Furthermore, 420,000 Children under 15 years were newly infected with HIV in 2007. Nearly $90 \%$ of all HIV-positive children live in sub-Saharan Africa [1]. About 780,000 were estimated to be in need of antiretroviral therapy [2]. The most efficient and cost effective way to tackle pediatric HIV globally is to reduce Mother to Children Transmission (MTCT). However, every day there are nearly 1200 new infections in children under 15 years of age with more than $90 \%$ of these occurring in the developing world and most being associated with MTCT [3].

Trials in the United States and Western Europe have demonstrated that HAART is effective in suppressing HIV viral replication and reversing immunodeficiency in children $[4,5]$. The result has been a reduction in pediatric hospital admissions and a decrease in morbidity and mortality due to HIV/AIDS [6-9]. The introduction of combination ART including protease inhibitors has resulted in striking reductions in HIV-related mortality [10-12]. However, these therapeutic regimens are very complex, often requiring that patients take numerous pills multiple times a day with specific timing and food restrictions or requirements. Failure to adhere very closely to the regimens appears to be related to continued viral replication, treatment failure and the emergence of drug-resistant strains of HIV [13$15]$.

In sub-Saharan Africa, AIDS has become one of the leading causes of mortality among children under the age of five years. Despite increased availability of ART, children remain a neglected population group [16]. However, many factors can affect the ability of HAART to suppress viral replication, including low potency of one of the drugs in the combination, viral resistance, inadequate drug exposure and inadequate adherence to therapy. The major factor determining the Success of HAART is sustainable and optimum adherence to therapy [17] as poor adherence increases the risk of virologic failure and viral resistance [18]. Therefore this study determines the rates and factors associated with adherence to ARV therapy among HIV-infected children who are receiving HAART in Addis Ababa, Ethiopia.

\section{Methods \\ Study area}

The study was conducted in selected hospitals in Addis Ababa city, the Capital City of the Federal Democratic Republic of Ethiopia. As of August 2007 the total number of children on ART in Ethiopia was 3865 [19]. The study was carried out in selected ART units in Addis Ababa Hos- pitals including Black Lion, St. Peter, Yekatit 12, Zewditu, and ALERT Hospitals. Among these, Black Lion Hospital is a teaching hospital under the Federal Ministry of Education. St. Paul Hospital is a General Specialized Hospital under the Federal Ministry of Health. St. Peter Hospital is a Generalized Hospital for TB treatment and they recently opened an ART clinic for adult and children. ALERT Hospital is also under the Federal Ministry of Health. Yekatit 12 and Zewditu Hospitals are under the Addis Ababa Regional Health Bureau, known to serve most of the patients on ART follow-up. This study was conducted from February 18 - April 28, 2008. The study design was a facility-based cross-sectional study.

\section{Participants}

The source populations were children who had been taking ARV and were on follow up in the ART units of the selected hospitals during the study period. The study population included sampled children who had been taking combination ARV medications who were on follow-up as well present during the data collection period. Children who fulfilled the following criteria were included in the study: Receiving continuous antiretroviral therapy for the last 12 weeks before study in the selected hospital and the caregiver (parents or guardians) was counseled on the importance of drug adherence and on how to recognize common adverse drug reactions associated with antiretroviral drugs. The exclusion criteria were: children who were terminally ill, age less than 3 months or greater than 14 years and a caregiver in a moribund state. The sample size was calculated using two proportions sample size formula using Epi Info (CDC, Atlanta, U.S.A., 2005) 6.04 statistical package. The following parameters were used to calculate the sample size: proportion of adherence (P1) among male children $33 \%$, proportion of adherence (P2) among female children $20 \%$ [20], $95 \% \mathrm{CI}$ and $80 \%$ power. This gave a sample size of 393 . Adding $10 \%$ for non-response rate, the total sample size was 433 . A simple random sampling technique was employed to identify the study units using the ART unique numbers from the registration book in each hospital.

\section{Measurements}

Data were collected by structured pre-tested questionnaire which was adopted from different studies [9,16-18]. The questionnaire was originally developed in English translated to Amharic and back translated to English by a translator who was blind to the original questionnaire. The content of the questionnaire included: socio-demographic characteristics (age of the child, sex of the child, age of the caregiver, ethnicity, educational status, occupational status of the caregiver); socio-economics conditions (monthly income, financial support for the child, grant for the child); medication related factors; health care delivery systems related factors including access to care, 
disclosure status of the children; perception related to the services, diagnosis, referral and treatment, and medication administration. Attitude was measured using a previously determined scale on attitude [16] where a set of 12 Likert scale questions addressed the attitude of the caregiver towards adherence. The independent variables were socio-economic status, socio-demographic factor, clinical characteristics (clinical stage of the children (World Health Organization stage I-IV) and CD4 cells/mm3 count of the children), perception related to the services (diagnosis, referral and treatment), medication administration including dosing. The dependent variable was caregivers' report adherence to ART in the past 7 days. A total of three days of intensive training was given to all supervisors and data collectors. The interview was conducted in private room to create an atmosphere of empathy and confidence. Medical charts were reviewed to collect clinical and immunological markers. The principal investigator and three general practitioners supervised the data collection process.

\section{Data analysis and processing}

Data entry and analyses were carried out using SPSS version 12.0.1 statistical packages. First, descriptive statistics were carried out to explore the socio-demographic characteristics of the respondents, the adherence rate and clinical characteristics of the children. To find association between the exposure variables and adherence, bivariate analysis was done. To control the effect of confounding variables, stepwise logistics regression was done. Variables which showed statistical significant association $(\mathrm{P}<0.05)$ in the bivariate analysis were included in the final model. To ensure quality of the data, pre-testing of the questionnaire was undertaken in 5 percent of the sample size in similar setups before the actual data collection took place. The final version of the questionnaire was used for the data collection. The overall activity was monitored by the principal investigator. There were strict supervisions during data collection. One trained data clerk entered and cleaned the data.

\section{Operational Definitions}

Adherence - a child is said to be adherent if he/she missed no more than one dose (took more than $95 \%$ of the prescribed doses correctly) for one week prior to the study.

Primary caregiver - a person who has consistently assumed responsibility for the housing, health, or safety of the child (individuals who administered the child medication daily and bringing the child for clinic appointments).

Attitude - twelve Likert Scale attitude questions were presented to respondents. One variable was computed using the sum of the 12 questions. If respondents score more than 36 , they were labeled as having favorable attitude. Unfavorable attitude was considered as a score less than 36.

\section{Ethical consideration}

Ethical clearance was obtained from Institutional Ethical Review Committee of Jimma University and Ethical clearance Committee of Addis Ababa Health Bureau. An official letter of co-operation from the above organization and Federal Ministry of Health (FMOH) was given to respective hospitals. Caregivers gave verbal informed consent for participating in the study.

\section{Results}

\section{Socio-demographic and economic characteristics}

A total of 390 children respondents were included in the study with response rate of $91 \%$. The majority 205 (52.6\%) of the children was above 9 years. The median age of the children was 9 years (range: 1 to 14 years). Fifty five percent of the children were girls. Most of the study participants were Amhara (53\%) and Oromo (24\%) by ethnicity. A majority (76.2\%) of the caregivers were orthodox by religion. Concerning the educational status of the caregiver, 176 , or $45.1 \%$, were in primary school. Regarding occupation, 103 (26.4\%) were daily laborers and 80 $(20.5 \%)$ were working as a government employee. One hundred seventy four (44.6\%) of the caregivers were married and 138 (35.4\%) were widowed. Three hundred seventy $(94.9 \%)$ of the respondents were the primary caregivers of the child. Two hundred forty (61.5\%) of the primary caregivers were biological parents of the children. The remaining were non-biological parents. The study subjects were on HAART for a mean and median duration of 20 and 24 months (12 to 48 month). One hundred sixty-two $(67.5 \%)$ of the biological parents serving as a caregiver were the biological mother of child (See table 1).

A large proportion of caregivers, equaling 277 (71\%), mentioned that no one had helped the child financially. Fathers (6.4\%) and local NGOs (6.4\%) were responsible to help some of the children. Of the 390 caregivers, 21.8 percent received a childcare grant. About 277 (71.4\%) of the respondents had household income levels below 500 Eth. Birr per month (Exchange rate 1 USD = 9.6 Ethiopian Birr (ETB)). (Data not presented)

\section{Clinical Markers of the Participants}

Most of the children (193 [49.5\%]) were in stage III based on WHO classification. The mean and median initial CD4 count were 273.28 cells $/ \mathrm{mm} 3$ and 203.00 cells $/ \mathrm{mm} 3$ respectively and 576.92 cells $/ \mathrm{mm} 3$ and 497.50 cells $/ \mathrm{mm} 3$ were the latest CD4 counts. One hundred ninety-four $(49.7 \%)$ of the children had a CD4 count of $<200$ cells/ $\mathrm{mm} 3$ at the start of the treatment. A similar number of children had CD 4 count of $>=500$ cells $/ \mathrm{mm} 3$. One hun- 
Table I: Demographic and social characteristics of caregiver and children in Addis Ababa, Ethiopia [N = 390], April 2008

\begin{tabular}{|c|c|c|c|}
\hline \multirow[t]{2}{*}{ Variable } & \multicolumn{2}{|c|}{ Frequency(percentage) } & \multirow[t]{2}{*}{$\mathrm{p}$-value } \\
\hline & Adherent & Non-adherent & \\
\hline Age (years) & & & 0.672 \\
\hline$<3$ & |4(4.I) & $I(2)$ & \\
\hline $3-5$ & $39(11.5)$ & $4(7.8)$ & \\
\hline $6-8$ & $111(32.7)$ & $16(31.4)$ & \\
\hline$>=9$ & $175(51.6)$ & $30(58.8)$ & \\
\hline Sex of the child & & & 0.347 \\
\hline Boy & 149(44) & $26(5 I)$ & \\
\hline Girl & $190(56)$ & 25(49) & \\
\hline Religion of the caregiver & & & 0.607 \\
\hline Orthodox & $261(77)$ & $36(70.6)$ & \\
\hline Catholic & $18(5.3)$ & $3(5.9)$ & \\
\hline Protestant & $37(10.9)$ & $8(15.7)$ & \\
\hline Muslim & 16(4.7) & $2(3.9)$ & \\
\hline Others $*$ & $7(2.1)$ & $2(3.9)$ & \\
\hline Occupational status of the caregiver & & & 0.343 \\
\hline Farmer & $0(0)$ & $4(7.8)$ & \\
\hline Merchant & $50(14.7)$ & $5(9.8)$ & \\
\hline Governmental employee & $52(15.3)$ & $6(11.8)$ & \\
\hline NGO employee & $28(8.3)$ & $\mathrm{I}(2)$ & \\
\hline Day laborer & $84(24.8)$ & $19(37.3)$ & \\
\hline Jobless/house made & $71(20.9)$ & $9(17.6)$ & \\
\hline Others ${ }^{t}$ & $54(15.9)$ & $7(13.7)$ & \\
\hline Marital status of the caregiver & & & 0.198 \\
\hline Single & $36(10.6)$ & $2(3.9)$ & \\
\hline Married & $154(45.4)$ & $20(39.2)$ & \\
\hline Divorced & $32(9.4)$ & $8(15.7)$ & \\
\hline Widowed & $117(34.5)$ & $2 \mid(4 \mid .2)$ & \\
\hline Educational status of the caregiver & & & 0.107 \\
\hline Unable to read and write & $75(22.1)$ & $19(37.3)$ & \\
\hline Primary $(I-8)$ & $157(46.3)$ & $19(37.3)$ & \\
\hline Secondary $(9-12)$ & $62(18.3)$ & 6(11.8) & \\
\hline Diploma and above & $45(13.3)$ & $7(13.7)$ & \\
\hline Are you the primary caregiver & & & 0.083 \\
\hline Yes & $320(94.4)$ & $5 I(100)$ & \\
\hline No & $19(5.6)$ & $0(0)$ & \\
\hline Who is the primary caregiver responsible for the child? & & & 0.296 \\
\hline Biological parents & $212(62.5)$ & $28(54.9)$ & \\
\hline Non-biological parents & $127(37.5)$ & $23(45.1)$ & \\
\hline Child HIV status disclosure & & & 0.001 \\
\hline Yes & $5 I(15)$ & $17(33.3)$ & \\
\hline No & $288(85)$ & $34(66.7)$ & \\
\hline Health care Provider's estimate of adherence & & & 0.001 \\
\hline Good & 295(87) & $32(62.7)$ & \\
\hline Fair & $9(11.5)$ & $\mathrm{II}(2 \mathrm{I} .6)$ & \\
\hline Poor & $5(1.5)$ & $8(15.7)$ & \\
\hline Monthly income in ETB & & & 0.154 \\
\hline$<105$ & $235(69.7)$ & $42(82.4)$ & \\
\hline $106-150$ & $45(13.4)$ & $5(9.8)$ & \\
\hline$|5|-262$ & $57(16.9)$ & $4(7.8)$ & \\
\hline Do you know when the child start treatment & & & 0.559 \\
\hline Yes & $296(87.3)$ & $46(90.2)$ & \\
\hline No & $43(12.7)$ & $5(9.8)$ & \\
\hline Duration of treatment in months & & & 0.278 \\
\hline$\leq 12$ & $100(29.5)$ & $2 I(4 \mid .2)$ & \\
\hline $13-24$ & $185(54.6)$ & $2 I(4 I .2)$ & \\
\hline $24-36$ & $44(13)$ & $8(15.7)$ & \\
\hline$\geq 36$ & $10(2.9)$ & $I(2)$ & \\
\hline
\end{tabular}


Table I: Demographic and social characteristics of caregiver and children in Addis Ababa, Ethiopia [N = 390], April 2008 (Continued)

\begin{tabular}{|c|c|c|}
\hline Care givers Attitude about Child ART & & \\
\hline Favorable & $330(97.3)$ & $50(98)$ \\
\hline Unfavorable & $9(2.7)$ & $\mathrm{I}(2)$ \\
\hline
\end{tabular}

Others*-.

Local, Jehovah witness

Others ${ }^{\epsilon}$ - secretary, cashier, carpenter

Exchange rate I USD = 9.6 Ethiopian Birr (ETB).

dred eleven children (30\%) had been taking the Stavudine (d4T)/Lamivudine (3TC)/Nevirapine (NVP) based regimen. About 115 (27\%) of the children were taking Zidovudine (AZT)/3TC/NVP and AZT/3TC/(Efavirenz) EFV for each regimen (See Table 2).

\section{Knowledge, Perceptions and Attitude about ARV Medications Administration}

Seventy percent of the participants (caregivers) had received information about ARV treatment from the hospitals (Government and Private). Overall, the participant attitudes on administration of ARV medication to the children were favorable in $380(97.4 \%)$ of the respondents with the 12 points Liker scale instrument (See Table 1).

\section{Medication Administrations and Adherence}

Caregivers used different mechanisms as reminders to administer medications on time; the most common reminder was cellular phone alarm systems $(25.4 \%)$ followed by watches/clocks (46.4\%). A total of 51 children
$(13.1 \%)$ omitted at least one dose of antiretroviral drugs in the past 7 days before the survey (See Table 3). For those who missed a dose or more in the last 7 days, the common reasons were lack of medication $(27.5 \%)$, child slept $(25.5 \%)$ and forgetfulness to give the drugs (23.5\%) (See Figure 1).

\section{Factors Associated With Pediatric Adherence to Antiretroviral Therapy}

After controlling the effects of other variables, five variables were found to be significantly associated with adherence to ART in children: As shown in Table 4, children whose parents did not pay a fee for treatment were $61.3 \%$ less likely to adhere for ART than those who paid for their medication [OR $=0.39$ (95\%CI: 0.16, 0.92)]. Similarly, children who had ever received any nutritional support from the clinic [PEM scheme, etc.] were $66.3 \%$ less likely to adhere to ART than those who did not get the nutritional support $[\mathrm{OR}=0.34(95 \% \mathrm{CI}: 0.14,0.79)]$. Children who took co-trimoxazole medication/syrup besides ARVs

Table 2: Clinical markers of HIV infected children in Addis Ababa, Ethiopia, [N = 390] April 2008

\begin{tabular}{|c|c|c|c|}
\hline \multirow[t]{2}{*}{ Variable } & \multicolumn{2}{|c|}{ Frequency(percentage) } & \multirow[t]{2}{*}{$\mathrm{p}$-value } \\
\hline & adherent & Non-adherent & \\
\hline WHO Clinical stage of HIV disease & & & 0.226 \\
\hline Stage I & $14(4.13)$ & $\mathrm{I}(2)$ & \\
\hline Stage II & $102(30.1)$ & $9(17.6)$ & \\
\hline Stage III & $163(48.07)$ & $30(58.8)$ & \\
\hline Stage IV & $60(17.7)$ & $I I(2 \mid .6)$ & \\
\hline CD4 counts at start of treatment & & & 0.377 \\
\hline$<200$ & $164(48.4)$ & $30(58.8)$ & \\
\hline $200-499$ & $|3|(38.6)$ & $16(31.4)$ & \\
\hline$>=500$ & $44(13)$ & $5(9.8)$ & \\
\hline Current CD4 count & & & 0.073 \\
\hline$<200$ & $45(13.3)$ & $12(23.5)$ & \\
\hline $200-499$ & $119(35.1)$ & $20(39.2)$ & \\
\hline$>=500$ & $175(5 \mid .6)$ & $19(37.3)$ & \\
\hline Regimen recommended & & & 0.105 \\
\hline $4 \mathrm{a}=\mathrm{d} 4 \mathrm{~T} / 3 \mathrm{TC} / \mathrm{NVP}$ & $103(30.4)$ & $16(31.4)$ & \\
\hline $4 \mathrm{~b}=\mathrm{d} 4 \mathrm{~T} / 3 \mathrm{TC} / \mathrm{EFV}$ & $53(15.6)$ & $9(17.6)$ & \\
\hline $4 c=A Z T / 3 T C / N V P$ & $97(28.6)$ & $7(13.7)$ & \\
\hline $4 \mathrm{~d}=\mathrm{AZT} / 3 \mathrm{TC} / \mathrm{EFV}$ & $86(25.4)$ & $19(37.3)$ & \\
\hline
\end{tabular}

$\mathrm{d} 4 \mathrm{~T}=$ Stavudine, $3 \mathrm{TC}=$ Lamivudine, $\mathrm{NVP}=$ Nevirapine, $\mathrm{AZT}=$ Zidovudine, $\mathrm{EFV}=$ Efavirenz 
Table 3: Caregivers' report adherence rate of HAART among children in Addis Ababa, Ethiopia, April 2008

\begin{tabular}{llll}
\hline Days & Adherent No(\%) & Non adherent No (\%) & Total \\
\hline Today & $383(98.2 \%)$ & $7(1.8 \%)$ & $390(100 \%)$ \\
Yesterday & $378(96.9 \%)$ & $12(3.1 \%)$ & $390(100 \%)$ \\
Past 3 days & $363(93.1 \%)$ & $27(6.9 \%)$ & $390(100 \%)$ \\
Past 7 days & $339(86.9 \%)$ & $51(13.1 \%)$ & $390(100 \%)$ \\
\hline
\end{tabular}

were 3.64 times more likely to adhere than those who did not take the co-trimoxazole [OR $=3.65(95 \% \mathrm{CI}: 1.24$, 10.74)]. Children who did not know their sero-status were 2.53 times more likely to adhere for the treatment of ARV than children who did know their sero-status [OR = 2.53 (95\%CI: 1.24, 5.19)]. Children who were not aware of their caregiver's health problem were 2.44 times more likely to adhere than children who had perceived awareness about the illness of the caregiver [OR $=2.45$ (95\%CI: $1.25,4.81)]$.

\section{Discussion}

This paper tries to examine the different variables associated with child adherence to antiretroviral therapy for in Ethiopia. Clinical record review, immunological markers and psychological and medication-related factors were assessed along with the caregiver characteristics to determine the predictors of adherence.

Adherence is a special issue in pediatrics not only because of social situations but also because many of the drugs are not child friendly [21]. This study found an estimated prevalence of caregivers' report of adherence to antiretroviral treatment to be $93.1 \%$ in 3 days and $86.9 \%$ in a 7 day recall period. Adherence rate in other studies ranged from $26 \%$ to $97 \%$ [22-30]. The possible explanations for the greater adherence in our study might be that the majority of the children started ART recently, the children were taking medication with a twice-daily dosing schedule, or the children and caregivers were given strict adherence counseling sessions before starting ART in the

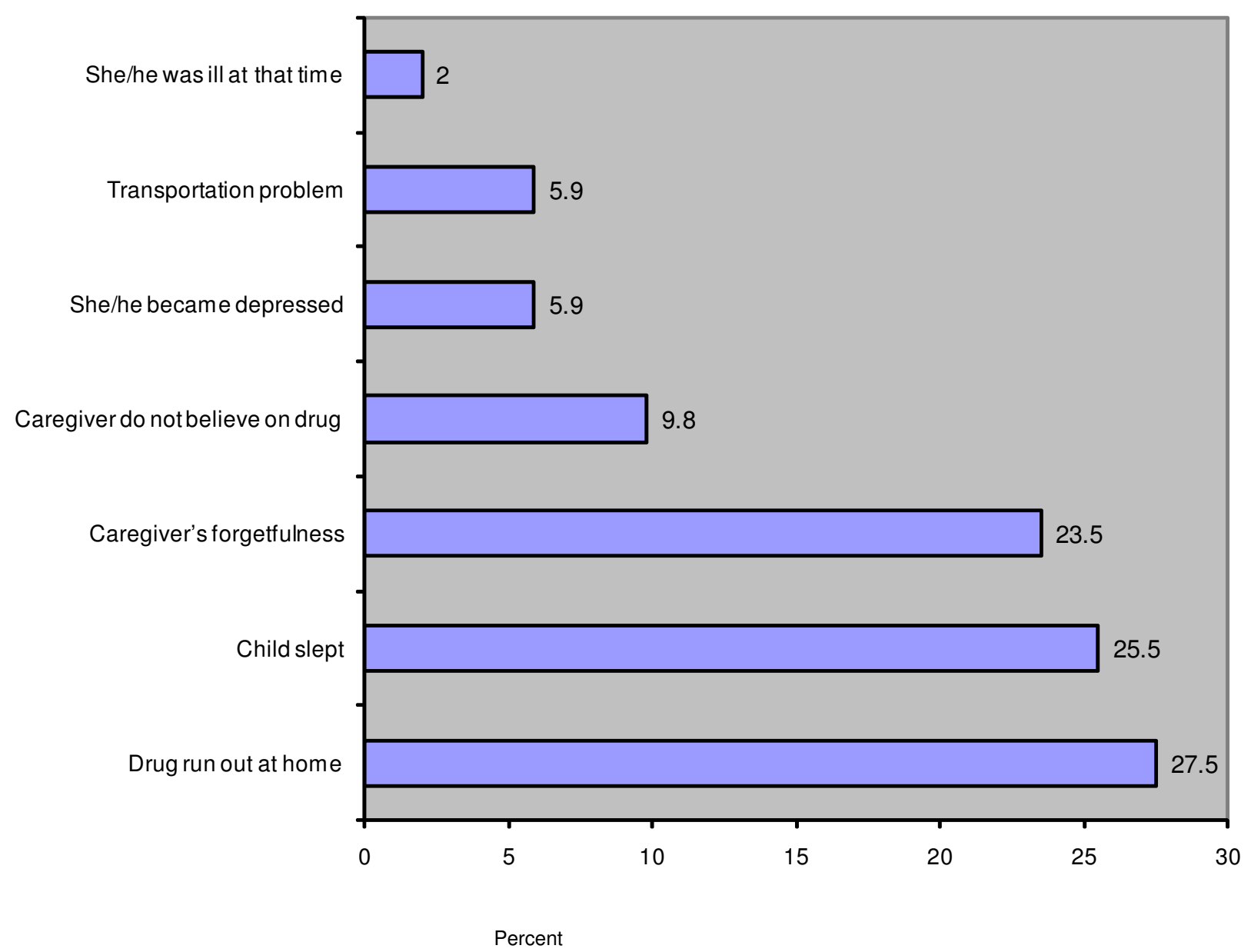

Figure I

Reasons for missing dose in children who were on HAART in Addis Ababa, Ethiopia, April 2008. 
Table 4: Independent predictors of adherence to ART among children in Addis Ababa, Ethiopia ( $\mathrm{n}=390$ ), April 2008

\begin{tabular}{|c|c|c|c|c|c|c|}
\hline \multirow[t]{2}{*}{ Variable } & \multicolumn{2}{|c|}{ Adherence Status } & \multirow[t]{2}{*}{ Crude OR $(95 \% \mathrm{Cl})$} & \multirow[t]{3}{*}{ P-value } & \multirow[t]{3}{*}{ Adjusted OR $(95 \% \mathrm{Cl})$} & \multirow[t]{2}{*}{ P-value } \\
\hline & Non-adherent & Adherent & & & & \\
\hline \multicolumn{5}{|c|}{$\begin{array}{l}\text { Medication charge for child treatment before ARV } \\
\text { intake }\end{array}$} & & \\
\hline YES & 7 & 104 & 1.00 & 0.016 & 1.00 & \\
\hline NO & 44 & 235 & $0.36(0.16,0.83)$ & & $0.39(0.16,0.92)$ & 0.033 \\
\hline \multicolumn{7}{|c|}{ Co-trimoxazole intake beside ARV } \\
\hline Yes & 44 & 324 & $3.44(1.33,8.93)$ & 0.011 & $3.65(1.24,10.74)$ & \\
\hline No & 7 & 15 & 1.00 & & 1.00 & 0.019 \\
\hline \multicolumn{7}{|c|}{$\begin{array}{l}\text { Perceived awareness of the child on health problem } \\
\text { of caregiver }\end{array}$} \\
\hline Yes & 20 & 63 & 1.00 & & 1.00 & 0.009 \\
\hline No & 31 & 276 & $2.826(I .51,5.28)$ & 0.001 & $2.45(I .25,4.8 I)$ & \\
\hline \multicolumn{7}{|c|}{ The child knows his/her sero-status } \\
\hline Yes & 17 & 51 & 1.00 & 0.002 & 1.00 & 0.011 \\
\hline No & 34 & 288 & $2.824(I .47,5.43)$ & & $2.53(1.24,5.19)$ & \\
\hline \multicolumn{7}{|c|}{ Received nutritional support from the clinic } \\
\hline Yes & 44 & 216 & $0.28(0.12,0.64)$ & 0.003 & $0.34(0.14,0.79)$ & 0.013 \\
\hline No & 7 & 123 & 1.00 & & 1.00 & \\
\hline
\end{tabular}

OR = Odds Ratio, $\mathrm{Cl}=$ Confidence Interval

hospitals and the majority of caregivers (97.4\%) had a favorable attitude toward administration of ARV to children.

In this study children whose caregivers paid for medication before ART were more adherer than those who did not pay. Hence, people tend to give value for their health when they spend money for treatment of their illness. Similarly, studies [31,32] revealed that costs have an implication for adherence. However, it varies at different stages of HIV infection, such that patient's who present late, especially if more immuno-suppressed, use more services at greater cost than those who are less immunosuppressed. An increasing adherence rate was observed in children with more advanced HIV [33]. Again, a similar pattern has been reported in adults [34,35].

One of the entry points that complicated the issue of adherence for HIV infected children is the issue of disclosure of HIV status to the child [36]. Studies showed that complete parental disclosure helps to motivate HIVinfected children to adhere to their daily medical regimen. It enables children to understand HIV infection and to make sense of disease-related experiences and the importance of adherence $[37,38]$. In this study, however nondisclosure had a significant relevance for adherence to the recommended regimen. It is consistent with other studies, which showed no effect of disclosure on adherence to ART $[22,39]$, which is also the case in the Multicenter National Study in Italy [33].

Interestingly, those who took co-trimoxazole prophylaxis besides taking ARV medications were more likely to adhere than those who did not use the treatment. Prophylaxis is probably at least as important as ART in preventing the onset of AIDS in children [40,41]. It is also supported by a study which revealed daily co-trimoxazole lays the groundwork for medication adherence by the patient and the establishment of reliable drug distribution systems [42]. Nutrition interventions can help to optimize the benefits of ARVs and may increase compliance with treatment regimens, both of which are essential to prolonging the Lives of People Living with HIV (PLHIV) and preventing the MTCT [43]. However; in our study receiving nutritional support from the clinic had an inverse relationship with adherence to ART therapy. In contrast to our finding, it is reported that one of the significant barriers to adherence was insufficient food and patients reported that lack of food prevented or delayed them taking their medication [44]. Provision of food and micronutrients has been shown to improve outcomes [4547]. In a South African study, many families spend more than $50 \%$ of their household income on food and food production and wage earnings were adversely affected when an adult has AIDS [48]. In the same line, poverty factors such as food insecurity and user fees for medical care, posed more significant barriers to adhering to longterm therapy than a patient's individual behavior. In a pilot program in Zambia on nutritional supplementation for food insecure patients on ART, it was shown that patients receiving food were on average 2.4 days late for their pharmacy appointments, whereas patients not receiving food were on average 3.4 days late each month. Patients receiving food were significantly adhered to pharmacy visits than patients not receiving food [49]. Surprisingly, in our study, adherence rates were significantly 
lower in those who received nutritional support than in those who did not. The inverse relationship between adherence to HAART and nutritional support is somewhat worrisome and needs to be investigated further in order to plan interventions in HIV infected children.

This study had some limitations and strengths. The main limitation of this study was recall bias. There is no gold standard assessment of adherence. In this study, adherence was measured using self-reports from the caregivers, which tends to overestimate the prevalence of adherence. The cross-sectional nature may hinder the ability to exactly identify the predictor of adherence, unlike a longitudinal design. Caregivers might be prone to social desirability bias responding inappropriately to the counselors. Adherence classification cutoff points may not be perfect in different setups to compare and contrast the finding. Despite the above limitations, the study had several strengths, including using a relatively large sample size, inclusion of several sites, use of more than one method of adherence assessment and inclusion of several variables.

\section{Conclusion}

From this research finding, it is concluded that caregivers' report adherence to HAART in children in Addis Ababa was $93 \%$ in the past 3 days and $87 \%$ in the past 7 days before the date of interview and it is acceptably higher than other similar setups. Children whose parents did not pay a fee for treatment, children who had ever received any nutritional support from the clinic were less likely to adhere. While children who took co-trimoxazole besides ARVs, children who did not know their sero-status and children who were not aware of their caregiver's health problem were more likely to adhere than their counterparts. To encourage child adherence to ART, using co-trimoxazole prophylaxis along with the delivery of ART might help. Further research is recommended to explore the relationship between disclosure and adherence and the effect of nutritional support on adherence.

\section{Competing interests}

The authors declare that they have no competing interests.

\section{Authors' contributions}

SB conceived and designed study, performed analysis and interpretation of data and drafted the manuscript. AD assisted with the design, interpretation of data and the critical review of the manuscript. AA assisted with the conception and designing the study and critically reviewed the manuscript. KD conceived and designed the study, critically reviewed the manuscript. All authors read and approved the final manuscript.

\section{Acknowledgements}

This study was carried out with the financial support obtained from Jimma University, Faculty of Public Health. We would like to extend our appreci- ation to Federal Ministry of Health and Addis Ababa Regional Health Bureau for providing the necessary information and facilitating conditions while carrying out this study. We are also very grateful and would like to extend our heartfelt thanks and appreciation to the study participants,

supervisors, data manager, and the data collectors (Nurse's counselors) and the staff at the institutions involved for their full participation, data collection and support. Jasmine, Kaley, Jenffier and Katey are acknowledged for editing the manuscript. BMC reviewers are thanked for the valuable comment on the manuscript.

\section{References}

I. UNAIDS/WHO: AIDS epidemic update2007. "UNAIDS/07.27E/ ICI 322E, Geneva Switzerland 2007.

2. WHO/UNAIDS: Antiretroviral therapy of HIV infection in infants and children in resource-limited settings: towards universal access: Recommendations for a public health approach. Geneva 2006.

3. WHO: World Health Organization Consultation on Nutrition and HIVIAIDS in Africa. Durban, South Africa.

4. Starr SE, Fletcher CV, Spector SA, Yong FH, Fenton T, Brundage RC, Manion D, Ruiz N, Gersten M, Becker M, McNamara J, Mofenson LM, Purdue L, Siminski S, Graham B, Kornhauser DM, Fiske W, Vincent C, Lischner HW, Dankner WM, Flynn PM: Combination therapy with efavirenz, nelfinavir, and nucleoside reverse-transcriptase inhibitors in children infected with human immunodeficiency virus type I. Pediatric AIDS Clinical Trials Group 382 Team. N Engl J Med 34I(25): I874-8I.

5. van Rossum AM, Geelen SP, Hartwig NG, Wolfs TF, Weemaes CM, Scherpbier HJ, van Lochem EG, Hop WC, Schutten M, Osterhaus AD, Burger DM, de Groot R: Results of 2 years of treatment with protease-inhibitor-containing antiretroviral therapy in dutch children infected with human immunodeficiency virus type I. Clin Ifect Dis 34(7): I008-16.

6. Resino S, Resino R, Maria Bellón J, Micheloud D, Gutiérrez MD, de José MI, Ramos JT, Fontelos PM, Ciria L, Muñoz-Fernández MA, Spanish Group of Pediatric HIV Infection: Clinical outcomes improve with highly active antiretroviral therapy in vertically HIV type-I-infected children. Clin Infect Dis 43(2):243-52.

7. Canani RB, Spagnuolo MI, Cirillo P, Guarino A: Decreased needs for hospital care and antibiotics in children with advanced HIV-I disease after protease inhibitor-containing combination therapy. AIDS I3(8): 1005-6.

8. Gortmaker SL, Hughes M, Cervia J, Brady M, Johnson GM, Seage GR 3rd, Song LY, Dankner WM, Oleske JM: Pediatric AIDS Clinical Trials Group Protocol 219 Team. Effect of combination therapy including protease inhibitors on mortality among children and adolescents infected with HIV-I. N Engl J Med 345(2I): I522-8.

9. de Martino M, Tovo PA, Balducci M, Galli L, Gabiano C, Rezza G, Pezzotti $P$ : Reduction in mortality with availability of antiretroviral therapy for children with perinatal HIV-I infection. Italian Register for HIV Infection in Children and the Italian National AIDS Registry. JAMA 284(2): 190-7.

10. Palella FJ Jr, Delaney KM, Moorman AC, Loveless MO, Fuhrer J, Satten GA, Aschman DJ, Holmberg SD: Declining morbidity and mortality among patients with advanced human immunodeficiency virus infection. HIV Outpatient Study Investigators. N Engl J Med 338( I 3):853-60.

II. Holtgrave DR: Causes of the decline in AIDS deaths, United States, 1995-2002: prevention, treatment or both? Int J STD AIDS 2005, I 6( I 2):777-8I.

12. Ventura SJ, Anderson RN, Martin JA, Smith BL: Births and deaths: preliminary data for 1997. Natl Vital Stat Rep I998, 47(4): I-4I.

13. Hecht FM, Colfax G, Swanson M, Chesney MA: Adherence and effectiveness of protease inhibitors in clinical practice. 5th Conference on Retroviruses and Opportunistic Infections. February 2-6, Chicago, Illinois 1998.

14. Montaner IS, Reiss P, Cooper D, Vella S, Harris M, Conway B, Wainberg MA, Smith D, Robinson P, Hall D, Myers M, Lange JM: A randomized, double-blind trial comparing combinations of nevirapine, didanosine, and zidovudine for HIV-infected patients: the INCAS Trial. Italy, The Netherlands, Canada and Australia Study. JAMA 279(I 2):930-7. 
15. Vanhove GF, Schapiro JM, Winters MA, Merigan TC, Blaschke TF: Patient compliance and drug failure in protease inhibitor monotherapy. JAMA 276(24): 1955-6.

16. Michaels Desireé, Eley Brian, Ndhlou Lewis, Rutenberg Naomi Exploring Current Practices in Pediatric ARV Rollout and Integration with Early Childhood Programs in South Africa: A Rapid Situational Analysis. University of Cape Town Horizons Program. The Population Council Inc 2006.

17. Starace F, Massa A, Amico KR, Fisher JD: Adherence to antiretroviral therapy: an empirical test of the information-motivation-behavioral skills model. Health Psychol 2006, 25(2): I53-62.

18. Nischal KC, Khopkar U, Saple DG: Improving adherence to antiretroviral therapy. Indian J Dermatol V'enereol Leprol 2005, $7 I(5): 316-320$.

19. Ministry of Health Ethiopia \& Federal HIVIAIDS Prevention and Control Office: Monthly HIV Care and ART Update end of August 2007. Addis Ababa, Ethiopia 2007.

20. Martinez J, Bell D, Camacho R, Henry-Reid LM, Bell M, Watson C, Rodriguez F: Adherence to antiviral drug regimens in HIVinfected adolescent patients engaged in care in a comprehensive adolescent and young adult clinic. I Natl Med Assoc 2000, 92(2):55-61

21. Working Group on Antiretroviral Therapy: National Pediatric HIV Resource Center. Antiretroviral therapy and medical management of the human immunodeficiency virus-infected child. Pediatr Infect Dis J 1993, I 2:5 I3-522.

22. Gibb DM, Goodall RL, Giacomet V, McGee L, Compagnucci A, Lyall $\mathrm{H}$ : Adherence to prescribed antiretroviral therapy in human immunodeficiency virus-infected children in the PENTA 5 trial. Pediatr Infect Dis J 2003, 22(I):56-62.

23. van Dyke RB, Lee S, Johnson GM, Wiznia A, Mohan K, Stanley K, Morse EV, Krogstad PA, Nachman S, Pediatric AIDS Clinical Trials Group Adherence Subcommittee Pediatric AIDS Clinical Trials Group 377 Study Team: Reported adherence as a determinant of response to highly active antiretroviral therapy in children who have Human Immunodeficiency virus infection. Pediatrics 2002, I09:e6I.

24. Watson DC, Farley J: Efficacy of and adherence to highly active antiretroviral therapy in children infected with human immunodeficiency virus type I. The Pediatric Infectious Disease Journal 1999, 18:682-696.

25. Feingold AR, Rutstein RM, Meislich D, Brown T, Rudy B]: Protease inhibitor therapy in HIV-infected children. AIDS Patient Care and STDs 2000, 14:589-602.

26. Boni S, Pontali E, DeGol P, Pedemonte P, Bassetti D: Compliance to combination antiretroviral therapy inHIV-I infected children. International Journal of Antimicrobial Agents. 2000, 16:682-696.

27. Temple ME, Koranyi K, Nahata MC: The safety and antiviral effect of protease inhibitors in children. Pharmacotherapy $200 \mathrm{I}$ 2I:287-294.

28. Byrne M, Honig J, Jurgrau A, Heffernan SM, Donahue MC: Achieving adherence with antiretroviral medications for pediatric HIV disease. AIDS Reader 2002, I 2:15I-164

29. Martin S, Elliott-DeSorbo DK, Wolters PL, Toledo-Tamula MA, Roby G, Zeichner S, Wood LV: Patient, caregiver and regimen characteristics associated with adherence to highly active antiretroviral therapy among HIV-infected children and adolescents. Pediatr Infect Dis / 2007, 26(I):6I-7.

30. Nabukeera-Barungi N, Kalyesubula I, Kekitiinwa A, Byakika-Tusiime J, Musoke P: Adherence to Antiretroviral Therapy in children attending Mulago Hospital, Kampala. Annals of Tropical pediatrics: International Child Health 2007, 27(2): I23-131.

31. Mandalia S, Parmar D, Fisher M, Pozniak a, Tang a, Youle M, on behalf of the NPMS-HHC Steering Group, et al.: Correlation between CD4 response and cost of hospital treatment in antiretroviral naïve HIV infected patients started on triple HAART. XIV International AIDS Conference, Barcelona, Spain; 2002.

32. Krenz HB, Auld MC, Gill MJ: The high cost of medical care for patients who present later (CD4 $<200$ cells/l) with HIV infection. HIV Med 2004, 5:93-98.

33. Giacomet V, Albano F, Starace F, de Franciscis A, Giaquinto C, Gattinara GC, Bruzzese E, Gabiano C, Galli L, Viganò A, Caselli D, Guarino $A:$ Adherence to antiretroviral therapy and its determinants in children with human immunodeficiency virus infection: a
Multicenter, national study. Acta Pediatr 2003, 92(I 2): 1398-1402

34. Samet JH, Libman H, Steger KA, Dhawan RK, Chen J, Shevitz AH, Dewees-Dunk R, Levenson S, Kufe D, Craven DE: Compliance with zidovudine therapy in patients infected with human immunodeficiency virus type I: a cross-sectional study in a municipal hospital clinic. Am J Med 1992, 92:495-502.

35. Singh N, Squier C, Sivek C, Wagener M, Nguyen MH, Yu VL: Determinants of compliance with antiretroviral therapy in patients with human immunodeficiency virus: prospective assessment with implications for enhancing compliance. AIDS Care 1996, 8:26I-9.

36. Mellins CA, Brackis-Cott E, Richards A, Abrams E: Patterns of HIV status disclosure to perinatally HIV-infected children and subsequent mental health outcomes. Clin Child Psychol Psychiatry 2003, 7:101-114.

37. Waugh S: Parental views on disclosure of diagnosis to their HIV-positive children. AIDS Care 2003, I5:169-176.

38. Blasini I, Chantry C, Cruz C, Ortiz L, Salabarría I, Scalley N, Matos B, Febo I, and Díaz C: Disclosure model for pediatric patients living with HIV in Puerto Rico: Design, implementation, and evaluation. Journal of Developmental and Behavioral Pediatrics 2004, 25: $181-189$.

39. Reddington C, Cohen J, Baldillo A, Toye M, Smith D, Kneut C, Demaria A, Bertolli J, Hsu HW: Adherence to medication regimens among children with human immunodeficiency virus infection. Pediatr Infect Dis J 2000, I 9( I 2): | | 48-53.

40. WHO: Guideline on cotrimoxazole prophylaxis's for HIV related infections among children, adolescent and adults: Recommendations for public health approach. World Health Organization; 2006

4I. Resino S, Bellón JM, Sánchez-Ramón S, Gurbindo D, Ruiz-Contreras J, León JA, Ramos JT, Muñóz-Fernández MA: Impact of antiretroviral protocols on dynamics of AIDS progression markers. Archives of Disease in Childhood 2002, 86: I I9-I24.

42. Mellins CA, Brackis-Cott E, Dolezal C, Abrams Ej: The role of psychosocial and family factors in adherence to antiretroviral treatment in human immunodeficiency virus-infected children. Pediatr Infect Dis / 2004, 23( I I): |035-4I.

43. World Bank: HIVIAIDS, Nutrition, And Food Security: what we can do. A Synthesis of International Guidance. 2007 [http:/ /www.ifpri.org/renewal/pdf/HIVAIDSNutritionFoodSec hires.pdf].

44. Angevine R, Bakeera-Kitaka S: Barriers to HAART adherence in a cohort of adolescents in urban Uganda. APHA 135th Annual Meeting and Expo. Washington DC.

45. Villamor E, Saathoff E, Manji K, Msamanga G, Hunter DJ, Fawzi WW: Vitamin supplements, socioeconomic status, and morbidity events as predictors of wasting in HIV-infected women from Tanzania. Am J Clin Nutr 2005, 82:857-865.

46. Ndekha MJ, Manary MJ, Ashorn P, Briend A: Home-based therapy with ready to- use therapeutic food is of benefit to malnourished, HIV-infected Malawian children. Acta Paediatr 2005, 94:222-225.

47. Fawzi WW, Msamanga GI, Spiegelman D, Wei R, Kapiga S, Villamor E, Mwakagile D, Mugusi F, Hertzmark E, Essex M, Hunter DJ: A randomized trial of multivitamin supplements and HIV disease progression and mortalit. N EnglJ Med 2004, 35 I:23-32.

48. Rutengwe RM: Identifying strategic interventions for improving household food and nutrition security in an urban informal settlement, South. Africa Asia Pac J Clin Nutr 2004, 13(Suppl):SI69.

49. Megazzini K, Washington S, Sinkala M, Lawson-Marriott S, Stringer E, Krebs D, Levy J, Chi B, Cantrell R, Zulu I, Mulenga L, Stringer J: Nutritional Supplementation for Food Insecure Patients on Antiretroviral Therapy: Impact of a Pilot Program in Zambia. In Centre for Infectious Disease Research in Zambia University of Alabama at Birmingham.

\section{Pre-publication history}

The pre-publication history for this paper can be accessed here:

http://www.biomedcentral.com/1471-2431/8/53/prepub 